\title{
DIFFICULT RELATIONSHIPS: HOW WILL COMPULSORY SCHOOL HISTORY AND AN UBUNTU-BASED CURRICULUM HELP NATION- BUILDING IN SOUTH AFRICA?
}

\author{
DOI: http://dx.doi.org/10.17159/2223-0386/2018/n19a1 \\ Reville Nussey \\ Muckleneuk campus, University of South Africa \\ rnussey@gmail.com
}

\section{Abstract}

Despite South Africa's shift to democracy, there are ongoing difficulties in relationships both in the broader society and schools. An official response to this situation was the establishment of the History Ministerial Task Team (MTT), which recommended: that history should be made a compulsory subject for learners in all phases at school; and, that the history curriculum should be revised using an African nationalist paradigm, informed by the framework of Ubuntu. This article uses the findings of a research project conducted in history classrooms at three primary schools in Johannesburg to illustrate some of the difficulties in relationships in the history classroom. It argues that compulsory history at school level will not necessarily be a panacea for South Africa's social ills, especially as this proposal has reawakened fears of how history education was abused during apartheid. A strength of the History MTT's report is that it emphasises the importance of multi-perspectives in history, while favouring an approach that uses an African nationalist paradigm, informed by Ubuntu, to assist with nation-building. However, the notion of Ubuntu needs to be reconstituted, and when applied in conjunction with reconciliation pedagogy, it provides an alternative way, during teacher development workshops, for in-service history teachers to reflect on their own residual prejudices about "the other", so that, in turn, they are able to facilitate meaningful changes in relationships in the history classroom. This approach might be applicable not only in South Africa, but also to history teachers in post-conflict countries which experience similar problems.

Keywords: Compulsory history; In-service history teachers; Multiperspectives; Nation-building; Reconciliation pedagogy; Ubuntu.

\section{Introduction}

Relationships in South African schools in the democratic era have revealed both continuities and challenges, as teachers and learners have grappled with the effects of political and social changes in the broader society on schools (Vandeyar, 2010). The shift to a democratic dispensation in 1994 did not lead to an overnight change in social awareness. There have been numerous 
examples which show the ongoing social and economic inequalities in South Africa, including overt and systemic racism entrenched in our schools, which continue two decades after the official end of apartheid.

One of the official responses to the ongoing problem of social divisions in South African society was to appoint a History Ministerial Task Team (MTT) in 2015 to investigate whether history should become a compulsory subject in the school curriculum, as "young people do not appreciate our country's history... and history is necessary to inspire the psyche of the nation" (Report of the History Ministerial Task Team for the Department of Basic Education [MTT], 2018:8). The final report recommended "that history should be made compulsory at FET [Further Education and Training] phase" (MTT, 2018:130)1. It also suggested that parts of the curriculum needed to change to include "African nationalism [which] is informed by the paradigm of progressive humanism underscored by Ubuntu" (MTT, 2018:46-47).

The idea of making history a compulsory subject at schools as a means towards nation-building has a particularly negative connotation in the South African context (Siebörger, 2016). One of the reasons for this is that during the apartheid era, there was an explicit connection made between history education, nation-building and the National Party. History education was seen as an instrument of propaganda that was used to justify a particular interpretation of the past, namely, that of the Afrikaner nationalists, and the result was history education that focused on an exclusive group and the result was that it "fomented hatred and conflict" (McCully, 2012:47). This has meant that in the democratic era, any attempt to link history education to a particular view of nation-building is viewed with suspicion in South Africa, and the call to make history compulsory in all phases in schools has reawakened this fear (Davids, 2016; Jansen, 2018). In addition, these suggested changes to South Africa's history school curriculum raise the following questions that this article will attempt to answer. First, will the compulsory study of history necessarily change social relationships in the classroom, and help with nationbuilding? Secondly, what role could Ubuntu play in this process? Finally, what are the implications for the development of in-service history teachers if history is made a compulsory subject?

1 History, in partnership with Geography, forms a subject called Social Sciences in the present curriculum, and it is compulsory until the end of Grade 9, which is the year before the start of the FET phase. 


\section{Background}

In order to explore possible answers to these questions, this article uses and reflects on some of the results of research conducted in three primary schools in Johannesburg, South Africa during 2009-2011, where a teacher educator observed between eight to sixteen history lessons in the primary school classroom and interviewed eight teachers. One of the aims of this research was to understand whether there were any long term effects on these teachers' practice of having done an oral history task on "Life before and after 1994", which formed the basis of a cooperative learning assignment when they were second year pre-service teachers doing a compulsory history methodology course. This course was part of their Bachelor of Education degree at the University of the Witwatersrand School of Education (WSoE). One of the aims of this assignment was to expose the students to the research process involved in oral history tasks and the pedagogy of cooperative learning. But there was another aim, that is, to address the issue of social divisions among the pre-service teachers that the teacher educator had observed in the lecture room.

A result of this oral history and cooperative learning assignment was that it started a process of breaking down social barriers among the students, and between the students and the teacher educator. It also led to a research project, which aimed to understand what had changed and why, as well as the development of a conception of a reconciliation pedagogy. By following a few of these pre-service teachers into the classroom once they became inservice history teachers in the intermediate phase primary school classroom, the following research questions were posed: Did the doing of this oral history and cooperative learning assignment at university have any effects on these teachers' practice once they were teaching in their own history classrooms? Secondly, what were the challenges and successes for in-service teachers adapting the university assignment to their primary school classrooms? Thirdly, what did the classroom observations reveal about the state of social relationships in history classroom at this level (Nussey, 2012)? For the purpose of this article, the focus will be on the third question, as a previous article (Nussey, 2017) has dealt with the first two questions.

This research was conducted prior to the call to make history compulsory throughout the school curriculum, but it raises important issues, which sheds light on whether the compulsory study of history necessarily affects relationships in the classroom in a positive manner. All the teachers in this research studied history at tertiary level as a result of a compulsory history 
methodology course. History, as part of social sciences, is a compulsory course for all learners in the intermediate phase at schools too. But the examples used in this article will focus on the teachers' interactions with their learners during the classroom observations, as a way to highlight some of the issues with social relationships in history classrooms.

\section{Data collection and research methodology}

The research sample was the result of purposive random sampling, as former history pre-service teachers from the WSoE who were now in-service history teachers at primary schools, were contacted and requested to participate in this research project. Ethical clearance to conduct this research was granted by the WSoE's ethics committee, the Gauteng Department of Education and principals of the schools. Furthermore, all the teachers volunteered to be part of this research project, which focused on the teaching of oral histories in the classroom. The sample consisted of six white teachers and two black teachers. While the majority of the learners were black at schools A and B, which were public schools, at school C, an independent school, there was an even mixture of black and white learners. Two of the schools were located in the northeastern suburbs, and one in the southern suburbs of Johannesburg.

As a direct observer in the classroom, I recorded my observations in a journal, and also interviewed each of the teachers using semi-structured, open-ended questions. These questions drew on the teachers' experiences in the present and past regarding issues such as, the use of oral history in the classroom, as well as their conceptions of identity and how they perceived relationships in their classrooms. The main focus of the project was on the teachers, so no follow-up interviews were conducted with the learners.

Each teacher was sent a copy of the transcribed interview for their comments or to allow for further clarification, so "member checking" (Harper \& Cole, 2012:1) was used. Finally, the journal observations and transcribed interviews were coded thematically, then analysed according to a qualitative framework as part of a narrative inquiry (Clandinin \& Connolly, 2000). While this is a small research sample, this qualitative research allows for a snapshot into some primary school history classrooms with regards to the state of relationships in this context.

Most of the teachers claimed that relationships were good among their learners and also between themselves and the learners in the classroom. Some of my observations supported this view of harmonious relations in the classroom, although there were numerous incidents that challenged this claim too. 


\section{Critical incidents and interviews ${ }^{2}$}

These critical incidents (Tripp, 1993:24) contested the teachers' views that relationships were good in the classrooms. They occurred during the classroom observations while the learners were discussing the results of their oral history interviews about life during apartheid with the teachers, and were raised with the teachers during their respective interviews.

At school B: a critical incident happened when a white boy shook his head to indicate a negative response when $\mathrm{Kagiso}^{3}$, a black teacher, requested volunteers to read their oral histories aloud. During an interview, I discussed this incident with Kagiso, and he explained that the reason for the boy's reaction was due to the derogatory content in his interview, and not that the boy felt shy to read it aloud. It appeared that either the boy made the choice to be silent rather than offend his peers or that he was scared to share his interview. The reason for the latter choice might be that he feared a negative reaction from his peers.

This critical incident showed the importance of being aware of the hurtful effects some of the oral histories could have on relationships, but it also showed the importance of a teacher creating a safe space in the classroom. While it might be argued that the teacher should respect the learner's choice to remain silent (as the teacher did in this case), a counter argument is that the silence about this past needs to be broken, so that a critical discussion takes place about what is being passed on via the oral histories. One of the reasons for this concern is that oral history tasks can be used as a vehicle to pass on trauma and prejudices between the generations (Hoffman, 2005; Jansen, 2009). There needs to be a process to address the way prejudices and trauma inform oral histories, so that these issues can be made explicit and dealt with as they arise.

At school C, another critical incident occurred when a few boys taunted another as a "Bushman" after he reported that his father said only a few young people went to school, because most were traditional and chose to go hunting. Joyce, a white teacher, dismissed the incident as an "inappropriate joke", although she did not "think it was a racial thing because they're all black". There is an ongoing debate as to what to call the indigenous first nation in South Africa: "San" is a term favoured by most historians, although "Bushmen" is being reclaimed as a positive term by some leaders and individuals within these communities (Hromnik, 2007:22). But the use of "Bushman" is still

2 The examples are taken from my unpublished PhD (Nussey, 2012).

3 To protect their anonymity, all the teachers' names are pseudonyms in this article. 
controversial, and it was used in a derogatory way by the boys. Joyce's view that the incident was not "racial" on the basis that the boys involved were "all black" was debatable, because there was a negative reference to difference in the original remark. In addition, this incident illustrated prejudice among these learners, as well as lack of awareness on the teacher's part.

During the class observations and interviews, some of the teachers' choice of words to describe "the other" also showed a lack of awareness. For example, at school C during Robyn's lesson, she described black people as "people of colour", which changed to "African" and then to "non-white". When questioned about the use of the term "non-white" during the interview after her lesson, Robyn responded that she did not want to "insult any of the children in my class ... and to make them upset". Yet, she acknowledged that she had changed words to describe black people during the lesson, although she had not "thought about" it before.

The term "non-white" was a blanket term used by apartheid authorities to refer to black people, whereas the term "black" was defined by Bantu Stephen Biko, a Black Consciousness leader, as referring to all the inhabitants in South Africa who were legally discriminated against by the apartheid regime, and who rejected this discrimination (Biko, 1971). This was an explicit rebuttal of apartheid's racial categories, namely, where black people were divided into African, Coloured and Indian, and Biko's definition regarding black people has continued to be used in South African discourse. There were many teachers in this research who used the term "non-white" without any awareness of either the historical origin of the word or how inappropriate its continued use was in a democratic present.

The above incidents reveal that there is a strong link between the difficulties in relationships in the broader society to those inside the classroom, which is hardly surprising, as a classroom can be seen as a microcosm of the broader society. But these incidents also showed contradictions between how the teachers saw their relationships with their learners and what their actions and words revealed. The words used to describe "the other", especially by the white teachers, demonstrated a lack of awareness of their own prejudices. There are a number of possible explanations, such as, these examples are evidence of a "hidden history curriculum" (Hues, 2011) at schools, and the continuity of white privilege (Conradie, 2015; Ellwanger, 2017). This situation is complex: it seems that there is an ongoing discomfort around racial identity in the present, based on what happened during apartheid, which needs to be 
addressed explicitly if there is any possibility of fostering positive relationships in the history classroom.

\section{Teachers' backgrounds and attitudes}

The teachers who participated in this research grew up during the last years of apartheid, and the majority of them attended schools that were desegregated. But this contact between the different races as children did not necessarily mean that the teachers were unaffected by the language that was used to construct racial identities during apartheid. This observation challenges "the most widely accepted theory of positive intergroup relations, namely, Allport's (1954) contact theory" (Slavin, 1985:11), namely, that if diverse groups come into contact with one another, then "relations between members of groups who have not previously interacted will improve following direct interpersonal interaction" (Miller \& Harrington, 1990:48). It also appeared that most of the white teachers' attitudes (as reflected in the language they used) did not shift substantially once they returned to schools as adults and taught classes that consisted of mainly black learners.

Walton (2013:1181) has suggested another possibility to explain these "contradictory attitudes", which was based on her research with learners and inclusive education. She argued that these "contradictory attitudes do not have to be explained away, but can be understood as young people expressing both a "discursive commitment to equality" (Young, 1990:124) and a "residual prejudice" (Fricker, 2007:39) that prevails in society." The contradiction here is between holding a genuine belief in equality for everyone, yet simultaneously harbouring a prejudice, which operates below the surface of one's awareness, and comes from the broader society. I have no doubt that the majority of teachers I observed were committed to fostering positive relationships among their learners, and between the learners and themselves. As Robyn stated, it was not her intention to "insult any of the children in my class". Yet the examples from the critical incidents and interviews with the teachers suggested that there are underlying problems with relationships in the primary school history classroom.

\section{Compulsory history education and teacher development}

These examples from the classroom observations and interviews showed that the studying of history by these teachers at tertiary level did not necessarily have much effect on changing their attitudes. Weldon (2010) has argued that South African history teachers need to address how their personal biographies affect 
their teaching in the classroom, and the findings of this research support this view. The History MTT report (2018:114) acknowledges that there will need to be teacher development for history teachers, if "History is made compulsory at FET phase". But if primary school history teachers, who have studied history methodology as part of a compulsory course during their second year BEd degrees at tertiary level, reveal these residual prejudices once they become inservice teachers, then how should future teachers be educated?

A report on the state of history education in South Africa identified numerous problems if history is to be made a compulsory subject, especially considering the reasons students choose to do history courses at tertiary level and how they are taught. These problems range from the low status of history education at institutions to the lack of a shared understanding by history educators as to the importance of developing pre-service teachers' historical thinking. However, the issue of addressing pre-service teachers' attitudes towards "the other" was not directly addressed, as the report's focus was mainly on how teacher educators approached the teaching of the discipline and their views on decolonising the curriculum (Bambo, Chisholm, Friedman \& Sindoh, 2017).

The argument in favour of making history compulsory at all levels at schools would need to address the above shortcomings: not only with regards to the learning and teaching of history, but also issues related to residual prejudices, which were revealed during this research. In particular, it seems that history teachers require additional skills in the mediating of difficult conversations and peace-building to deal with difficulties in relationships inside the history classroom.

\section{Ubuntu: Overview}

One of the answers that the MTT report (2018:46) suggests to deal with this issue of the difficulties in social relationships is for the history curriculum to be informed by a philosophical framework based on Ubuntu. The application of Ubuntu to an educational context is not a novel idea, and there has been a call to apply this concept as a solution to some of the problems in international and online education (Piper, 2016; Waghid, Waghid \& Waghid, 2018). However, the meaning of the concept of Ubuntu has generated considerable controversy, as it is used differently in diverse discourses (Hankela, 2014).

Among some commentators, there is a tendency to dismiss the value of Ubuntu as a populist idea, which is based on the notion that Ubuntu can be translated and reduced to a single phrase, "I am because you are" (Breed \& Semenya, 2015:6). Others argue that there is a tendency to oversimplify a complex 
concept where some Africanist scholars have translated Ubuntu's meaning as African "humanism" (Eze, 2010:90), which is close to the definition of Ubuntu in the MTT report (2018:46), where it is defined as a philosophy of "progressive humanism". This means that the value of Ubuntu underpinning the MTT report could be dismissed in a similar manner, especially as it includes a wide variety of concepts, such as, "human sympathy, human rights, social justice, love, willingness to share, and forgiveness" (2018:47), which the report fails to define. Another argument, against the use of Ubuntu, is that it has become so conceptually thin that the term has lost its meaning in a modern, global world (Matolino \& Kwindingwi, 2013). These criticisms raise serious concerns about using Ubuntu as a philosophical framework to underpin a history curriculum that is compulsory for all learners.

However, while acknowledging the validity of some of these criticisms, a counter argument has emerged that it is possible to rethink and reconstitute the meaning of Ubuntu (Praeg \& Magadla, 2014), so that this term can provide the basis for an ethical world view (Metz, 2014). In addition, Eze (2010:160-161) has argued that Ubuntu provided a modern ideological basis for a "flexible" notion of nation-building which emerged during the Truth and Reconciliation Commission (TRC):

In theory, ubuntu is a hermeneutic process that remains inclusive but allows one to dialogue with people from other historical cultures while being sensitive to differences in context and other historical cultures and traditions. Even if an invented ideology, it still yields an imagination that tries to reconcile the very often conflicting memories of South Africa, not into a single homogeneous consciousness but by bringing these memories into dialogue with one another.

Eze has reconstituted Ubuntu as an inclusive approach, while acknowledging differences, and encouraging "a creative dialogue [which] is a dialogue that is flexible, dialogic and mutually transformative" (Eze, 2010:154). Another approach suggests that Ubuntu can be understood as "an ethic of care" (Waghid \& Smeyers, 2012:20); and, finally, Ubuntu can be used to inform a process of building peace (Murithi, 2009). All of these ideas could be used with inservice history teachers during teacher workshops to encourage reflection on their own positionality and prejudices, and to facilitate difficult conversations which might help them to shift their own, and their learners' approaches, to "the other" in their respective classrooms. 


\section{Ubuntu and a reconciliation pedagogy}

I have previously suggested that a reconciliation pedagogy, which uses an oral history task, cooperative learning and is informed by a theoretical framework, namely, Lederach's (1999) "dance" of reconciliation, was a way of addressing some of the problem of relationships in the history lecture room with pre-service teachers (Nussey, 2014). However, a reconstituted notion of Ubuntu adds to and deepens the theoretical and practical framework that informs a reconciliation pedagogy, and this approach could be used with inservice history teachers in all phases during teacher development workshops. This could help to address residual prejudices and to introduce different approaches to the teaching of history as required by the proposed curriculum.

Eze's (2010) idea of Ubuntu as memories being brought into a creative dialogue with one another is relevant to a reconciliation pedagogy, which uses an oral history task as part of its process. History teachers, who lived most of their lives under apartheid, can be interviewed by those who grew up at the tail end of apartheid or those born after the advent of democracy. The oral history interview provides an opportunity to bring the different memories of two or more generations into conversation with one another, where a distinction can be made between "lived" and "learnt" memory (Wineburg, 2001:234). This allows for those who lived during apartheid, and the members of the second or third generation to engage with one another, and also for multiperspectives of this past to emerge.

In addition, the oral history interviews also provide an opportunity for the second and third generation to pose questions about this difficult past to members of the first generation, which opens up a space for a creative dialogue between the generations at a workshop. By doing so, this dialogue has the potential to uncover residual prejudices, yet also facilitate the reweaving of relationships between the generations, and in this sense becomes "mutually transformative" (Eze, 2010:154). However, the success of this process depends on how the interviews are conducted, and Waghid and Smeyers's (2012:20) conception of Ubuntu "as a particular ethic of care" which relies on "empathy and relational autonomy" plays an important role during the interview process, especially as there are many traumatic events that have occurred in South Africa's past.

Another part of a reconciliation pedagogy that requires an "ethic of care" is a cooperative learning task (Johnson \& Johnson, 2010), which uses the oral history interviews as the basis for a joint task in heterogeneous groups. In the 
case of in-service teacher workshops, where the participants are from diverse backgrounds, a joint task allows for the members of the same group who are from "other historical cultures" (Eze, 2010:160) to share the results of their oral history interviews with one another. This provides an opportunity to broaden the dialogue about the past within a larger group, and empathy is crucial during this process, as traumatic narratives may be shared.

While the concept of empathy is considered controversial in history education, Barton and Levstik (2004:208) have argued in favour of historical empathy in two ways. The first way is to encourage the recognition of different perspectives in the past as a rational exercise. This means that an aim is not simply to understand diverse views, but to "contextualise" them within the framework of historical actors, so that those in the present can see the coherence of historical actors' diverse views about the past. Situating this oral history task within the framework of Ubuntu encourages the teachers to grapple with multi-perspectives, which also helps to challenge the view that there is a single story about the past (Wielanga, 2013).

The MTT's report (2018:40-41) envisages a learner/student who is "a critically skilled citizen who is capable of handling multiple kinds of perspectives", which implies that the learners are encouraged to explore a plurality of perspectives, understood as "both diversity of past historical perspectives as well as diversity of present understandings of the past" (Klein, 2010:615). This is an approach which uses the discipline of history to inform critical reflection on events from different perspectives, as well as to explore how historical narratives are constructed (Barton \& McCully, 2010). It is this aspect of the HMTT report that "promotes the idea that school history should be about teaching young people to think critically about the past and the present" (Kallaway, 2018).

However, many in-service teachers in South Africa have not necessarily been exposed to an approach to the teaching of history that encourages using a plurality of perspectives. This means that it will be difficult for these teachers to implement this approach in their classrooms. By attending workshops that use a reconciliation pedagogy informed by Ubuntu, teachers are able to experience multi-perspectives in practice. It also provides an opportunity for teachers to reflect on the challenges of dealing with differing perspectives, but it might enable them to implement this important aspect of the proposed curriculum in their classrooms too. 
The second way that Barton and Levstick (2004:208) conceptualise empathy in history education is to foster an emotional response that encourages care about the injustices of the past, so that present-day injustices are challenged too. Yet, when dealing with issues such as injustices in the past and present, this can lead to conflict within the cooperative groups. This means that there needs to be an approach to building peace, which another conception of Ubuntu provides.

\section{Ubuntu and building peace}

Murithi (2009) has suggested that using Ubuntu was a way to build peace in a village in Africa, and that this approach could be applied to education too. He described the following five steps on how to use Ubuntu in a peace process within a community:

Firstly, after the facts had been ascertained by hearing the views of victims, perpetrators and witnesses, the perpetrator - if considered to have done wrong - would be encouraged, both by the Council and other community members in the inkundlallekgotla forum, to acknowledge responsibility or guilt. Secondly, the perpetrator would be encouraged to repent or to demonstrate genuine remorse. Thirdly, the perpetrator would be encouraged to ask for forgiveness and the victim in turn would be encouraged to show mercy. Fourthly, where possible and at the suggestion of the Council of Elders, the perpetrator would be required to pay appropriate compensation or reparations for the wrong done.... The fifth stage sought to consolidate the process as a whole by encouraging the parties to commit themselves to reconciliation. This process of reconciliation tended to include the victim and his or her family members and friends, as well as the perpetrator and his or her family members and friends [emphasis in the original] (Murithi, 2009:228-229).

These steps can be used as a guideline for a role play/simulation for the joint, cooperative learning group task, based on the results of the oral history interviews during the in-service teachers' workshops. Using Ubuntu to inform a peace-building process and Lederach's (1999) ideas of the dance of reconciliation will help teachers to engage with the "big ideas", such as truth, apology, mercy and restitution that are vital to consider when building peace. By applying these ideas to the teachers' oral history interviews and the cooperative task, it encourages them to engage in further dialogue with one another from a different, broader perspective. The debriefing process at the end of workshops offers an opportunity for further reflection, and for teachers to discuss how and when it is appropriate for this approach to be applied to the history classroom. 


\section{Conclusion}

The making of history as a compulsory subject throughout the school curriculum will not necessarily act as a panacea for South Africa's social ills. The critical incidents and interviews provided a snapshot into some primary school history classrooms, which showed ongoing tensions in relationships. Nonetheless, they illustrated the need for many participants in this research to reflect and be challenged on their assumptions about "the other". For some of the teachers, it was important for them to become aware of the contradictions between residual prejudices and their words and actions towards their learners. In the case of the learners, there was a need to address their prejudices explicitly, so that this could start a dialogue that encouraged a positive shift in attitude towards "the other". These changes in social relationships do not happen naturally as a result of contact between the races in the classroom or by the compulsory studying of history. All the teachers involved in this research had studied history methodology beyond their schooling. This research showed that this compulsory study had had a limited effect on their ability to deal with difficult social relationships as they arose in the intermediate phase classroom, where history is a compulsory part of the curriculum.

A reconciliation pedagogy, informed by a reconstituted notion of Ubuntu, which incorporates the ideas of Eze's (2010:154) "creative dialogue" and Waghid and Smeyers's (2012:20) "ethic of care", could play a role in addressing some of these issues during in-service teacher workshops for teachers who teach history in all phases. There are many tasks that inform this peacebuilding process: the oral history interviews between different generations of history teachers, which allows for the sharing of narratives from different perspectives; the application of historical empathy, understood as promoting both rational and emotional engagement with the past and the present, during the preparation and presentation of a cooperative learning task based on the results of the oral history interviews; and, by engaging with the "big ideas" found in Lederach's (1999) dance of reconciliation and Murithi's (2009) conception of Ubuntu informing a peace-building process. While this will be a time-consuming process, it provides the space for history teachers to engage with and reflect on social residual prejudices in a way that aims to encourage meaningful shifts in their personal attitudes, and by extension, will help them to facilitate change in relationships in their history classrooms.

Irrespective of whether history becomes a compulsory subject throughout the school curriculum or not, the History MTT report and reactions to it 
have highlighted the need for different approaches to the development of preservice and in-service history teachers. The recommendation to make history a compulsory subject throughout the school curriculum will not necessarily address the lack of social cohesion in South Africa. As Francis and Hemson (2007:30) state, "[t]eachers have a role to play in dismantling oppression and generating a vision for a more socially just future", and a reconciliation pedagogy, informed by a reconstituted conception of Ubuntu, could assist history teachers with this process. This approach might be applicable, not only in South Africa, but also to history teachers in post-conflict countries which are experiencing similar problems.

\section{References}

Bambo, N, Chisholm, L, Friedman M \& Sindoh, AQ 2017. Decolonising the teacher education curriculum: Mapping the status and nature of teaching and learning of history in faculties and schools of education in South Africa. Johannesburg: University of Johannesburg \& University of the Witwatersrand.

Barton, KC \& Levstik, LS 2004. Teaching History for the common good. Mahwah, NJ: Erlbaum Associates.

Barton, KC \& McCully, AW 2010. "You can form your own point of view": Internally persuasive discourse in Northern Ireland students' encounters with history. Teachers College Record, 112 (1):142-181.

Biko, BS 1971. The definition of Black Consciousness. Available at https://www.sahistory. org.za/archive/definition-black-consciousness-bantu-stephen-biko-december1971-south-africa. Accessed on 5 June 2018.

Breed, G \& Semenya, K 2015. Ubuntu, koinonia and diakonia, a way to reconciliation in South Africa? HTS Teologiese Studies/Theological Studies, 71(2):1-9.

Clandinin, DJ \& Connelly, FM 2000. Narrative Inquiry. San Francisco: Jossey-Bass.

Conradie, M 2015. Each colour in its own place: Positioning whiteness in South Africa through the race talk of undergraduate students. Race, Gender and Class, 22(12): $1-21$.

Davids, M 2016. “Making History compulsory”: Politically inspired or pedagogically justifiable? Yesterday \& Today, 15:84-102.

Ellwanger, A 2017. No exit: White speech and silence in classroom conversations on race. Pedagogy, 17(1):35-58. 
Eze, M 2010. Intellectual History in Contemporary South Africa. New York: Palgrave MacMillan.

Francis, D \& Hemson, C 2007. Rainbow's end: Consciousness and enactment in socially just education. Perspectives in Education, 25(1):99-112.

Hankela, E 2014. Ubuntu, migration, and ministry: Being human in a Johannesburg church. Leiden: Koninklijke Brill.

Harper, M \& Cole, P 2012. Member checking: Can benefits be gained similar to group therapy? The Qualitative Report, 17(2):510-517.

Hoffman, E 2005. After Such Knowledge: A Meditation on the Aftermath of the Holocaust. London: Vintage.

Hromnik, C 2007. Free the ottentotu from the idealogues. Sunday Times, 15 April.

Hues, H 2011. 'Mandela, the terrorist': Intended and hidden history curriculum in South Africa. Journal of Educational Media, Memory and Society, 3(2):74-95.

Jansen, JD 2009. Knowledge in the blood. Stanford: Stanford University Press.

Jansen, JD 2018. You don't fool us with your history plan, Minister. The Times, 7 June. Available at https://select.timeslive.co.za/ideas/2018-06-07-you-cant-fool-uswith-your-forced-history-plan-minister/. Accessed on 30 June 2018.

Johnson, DW \& Johnson RT 2010. Peace education in the classroom: Creating effective peace education programs. In: G Salomon \& E Cairns (eds.). Handbook on Peace Education. New York: Psychology Press.

Kallaway, P 2018. Whither the crucial teaching of history? City Press, 17 June. Available at https://www.news24.com/Columnists/GuestColumn/whither-the-crucialteaching-of-history-20180615. Accessed on 15 July 2018.

Klein, S 2010. Teaching history in the Netherlands: Teachers' experiences of a plurality of perspectives. Curriculum Inquiry, 40(5):614-634.

Lederach, JP 1999. The Journey toward Reconciliation. Scottdale: Herald Press.

Matolino, B \& Kwindingwi W 2013. The end of Ubuntu. South African Journal of Philosophy, 32(2):197-205.

McCully, AW 2012. History teaching, conflict and the legacy of the past. Education, Citizenship and Social Justice, 7(2):145-159. 
Metz, T 2014. Just the beginning for ubuntu: Reply to Matolino and Kwindingwi. South African Journal of Philosophy, 33(1):65-72.

Miller, N \& Harrington HJ 1990. A situational identity perspective on cultural diversity and teamwork in the classroom. In: S Sharan (ed.). Cooperative Learning. New York: Praeger.

Murithi, T 2009. An African perspective on peace education: Ubuntu lessons in reconciliation. International Review of Education, 55(2): 221-223.

Nussey, RJ 2012. The challenges and limitations of developing a "reconciliatory pedagogy" using oral history with South African pre-service and in-service history teachers. Unpublished PhD thesis. Johannesburg, University of the Witwatersrand.

Nussey, RJ 2014. The "dance" of reconciliation: Understanding the complex steps in a reconciliation pedagogy using an oral history assignment. Yesterday \& Today, $12: 1-27$.

Nussey, RJ 2017. Experimenting with a reconciliation pedagogy in South African primary school history classrooms: Constraints and possibilities. African Journal on Conflict Resolution, 17(2):93-116.

Piper B 2016. International education is a broken field: Can ubuntu education bring solutions? International Review of Education, 62:101-111.

Praeg, L \& Magadla S (eds.) 2014. Ubuntu: Curating the archive. Scottsville: University of KwaZulu-Natal.

Report of the History Ministerial Task Team for the Department of Basic Education [MTT] 2018. Available at https://www.education.gov.za/Portals/0/Documents/ Reports/Report\%20of\%20the\%20History\%20Ministerial\%20Task\%20 Team.pdf?ver=2018-06-07-154241-410. Accessed on 5 June 2018.

Slavin, R 1985. An introduction to cooperative learning research. In: R Slavin, S Sharan, S Kagan, W Hertz-Lazarowitz \& R Schmuck R (eds.). Learning to coperate, cooperating to Learn. New York: Plenum Press.

Siebörger, R 2016. Defining history as a school subject. Public History Weekly 4(1), http:// public-history-weekly.oldenbourg-verlag.de/4-2016-1/defining-history-schoolsubject/. Accessed on 15 August 2016.

Tripp, D 1993. Critical incidents in teaching. Routledge: London.

Vandeyar, S 2010. Responses of South African teachers to the challenge of school integration. South African Journal of Education, 30(37):343-359. 
Waghid, Y \& Smeyers, P 2012. Reconsidering ubuntu: On the educational potential of a particular ethic of care. Educational Philosophy and Theory, 44:6-20.

Waghid, Y, Waghid, F \& Waghid, Z 2018. Rupturing African philosophy on teaching and learning. New York: Palgrave MacMillan.

Walton, E 2013. Inclusion in a South African high school? Reporting and reflecting on what learners say. International Journal of Inclusive Education, 17(11):1171-1185.

Weldon, G 2010. Post-conflict teacher development: Facing the past in South Africa. Journal of Moral Education, 39(3):353-364.

Wielanga, C 2013. Healing and reconciliation after violent conflict: The role of memory in South Africa and Rwanda. Acta Academica, 45(1):209-231.

Wineburg, S 2001. Historical Thinking and Other Unnatural Acts. Philadelphia: Temple University Press. 